\title{
Maternal deaths where do they occur? A survey of health facilities in Abia state, south east Nigeria
}

\author{
Christian C. I beh, Patricia U. Okpala \\ Department of community medicine, nnamdi azikiwe university teaching hospital, nnewi, anambra state, Nigeria \\ Correspondence: Christian C. I beh. Address: Department of community medicine, nnamdi azikiwe university teaching \\ hospital, nnewi, anambra state, Nigeria. Email: christiancibeh@yahoo.com.
}

Received: May 9, 2012

Accepted: October 7, 2012

Online Published: November 29, 2012

DOI : $10.5430 /$ jnep.v3n3p139

URL: http://dx.doi.org/10.5430/jnep.v3n3p139

\begin{abstract}
Ascertaining the burden of maternal mortality is crucial to the improvement of maternal health for any nation. It provides basis to evolve comprehensive strategies to enhance mothers' health.

A facility-based survey was carried out in Abia State southeast Nigeria in 2003 to determine the magnitude of maternal deaths and where they occur in the State. Health facilities in the 17 local government areas of the State were enlisted. Data on births and maternal deaths in the preceding 12 months were obtained.

A total of 25,081 births and 43 maternal deaths were recorded for the study period giving maternal mortality rate of $171 / 100,000$. The public facilities had higher value of maternal mortality rate $(856.8 / 100,000)$ than the private (177.2/100,000). Similarly, the Comprehensive Essential Obstetric Care facilities had lower maternal mortality rate than the Non-Essential Obstetric Care. Poor documentation may be one of the reasons for the low maternal mortality rate in this study. Enforcing proper documentation, reporting and investigation of maternal deaths is hereby recommended.
\end{abstract}

\section{Key words}

Maternal mortality, Health facilities, Essential obstetric care

\section{I ntroduction}

Approximately 600,000 women die annually from complications of pregnancy, child bearing and unsafe abortions worldwide ${ }^{[1-3]}$. About $99 \%$ of these deaths occur in the developing world ${ }^{[1,2]}$. Unfortunately, most of the affected countries have difficulties ascertaining their burden of maternal mortality, as the estimates are highly susceptible to inaccuracies ${ }^{[2,4,5]}$. The difficulties in obtaining accurate data on maternal mortalities have created the need to explore other techniques that would give more reliable data. Some advocate the use of the sisterhood method of estimating maternal mortality. However, the sisterhood method is still being refined and the extent and impact of biases have only recently received attention ${ }^{[6]}$. Others advocate community-based surveys where maternal deaths are investigated by assessing records of health facilities and augmenting it with verbal autopsies of maternal deaths in the communities ${ }^{[5,7]}$. In the interim, the World Health organization has recommended a number of process indicators to monitor the effect of health programmes on maternal mortality in the developing world ${ }^{[8]}$. This only goes to reveal the exasperation experienced by experts in dealing with maternal mortality data in the third world. For example, for two consecutive periods (1999 and 2003), the Nigerian Demographic and Health Survey (DHS) have been unable to come out with a national value of 
maternal mortality rate (MMR) for the Country as a result of the aforementioned difficulties ${ }^{[9,10]}$. The 2008 DHS for Nigeria provides MMR of 545/100,000 which is an improvement of the previous value of 800/100,000. However while the MMR for the country reduced by about a third, the proximate determinants of MMR for the country (skilled attendance at birth, proportion of births delivered at facilities, proportion of mothers receiving antenatal clinic (ANC) services, etc) did not show commensurate improvement over the same period ${ }^{[11]}$.

Reviews of pregnancy related deaths by nations are important public health functions ${ }^{[12]}$. Every pregnancy related death need to be reported and investigated. In countries where this is enforced, data on maternal deaths is available and it enables them to adopt comprehensive strategies to tackle maternal health problems ${ }^{[13-15]}$.

A survey was carried out on health facilities in Abia State, southeast Nigeria to determine the magnitude of maternal deaths and where they occur in the State. This was part of the National Study on Essential Obstetric Care (EOC) in Nigeria carried out by United Nations Population Fund (UNFPA) and the Federal Ministry of Health in 2003.

\section{Materials and methods}

A facility-based assessment of maternal deaths was carried out in Abia State southeast Nigeria to determine the magnitude of maternal deaths and where they occur in the State. This was part of a national survey of Essential Obstetric Care facilities. All the seventeen Local Government Areas (LGAs) in the State were enlisted into the study. The list of all health facilities in each LGA was obtained. A two day training was organized for 20 senior nurse-midwives and 2 sociologist assistants on the study methodology. These served as the data collectors for the study which lasted for 4 weeks. A standard questionnaire adapted from previous studies on maternal mortalities was used for the survey ${ }^{[16-18]}$. Detailed information on child delivery and maternal deaths recorded in health facilities in the preceding 12-months were obtained. These included type of facility, nature of services offered, categories and number of staff, instruments and medical consumables available and data on clients attended to including the number of deliveries recorded (life and stillbirths) etc. The survey depended on data provided on health facility registers. In facilities were the information is not summarised in registers, the data collectors who are senior health workers (nurse-midwives) extracted the data from patient case notes. The types of maternal services offered in the facilities were noted and were used to categorize them into 3 groups using the following criteria:

1) Parenteral antibiotics

2) Parenteral oxytocics

3) Parenteral sedatives

4) Manual removal of placenta

5) Removal of retained products of conception

6) Assisted vaginal delivery

7) Blood transfusion

8) Caesarean section

Facilities that do not offer any one of the services numbered 1 to 6 were classed as Non-Essential Obstetric Care. Facilities that offer all the services numbered 1 to 6 were classed as Basic Essential Obstetric Care. Facilities that offer all the services numbered 1 to 8 were classed as Comprehensive Essential Obstetric Care. 


\section{Results}

A total of 370 health facilities that offer maternal services were surveyed in the 17 Local Government Areas of the State. These were made up of 215 Primary Health Centres/Maternity Homes (both public and private facilities) and 155 secondary/tertiary health care facilities. There were a total 249 (67.3\%) health facilities that did not meet the criteria for Essential Obstetric Care while those that met the criteria for Basic Essential Obstetric Care and Comprehensive Essential Obstetric Care were 42 (11.4\%) and 79 (21.4\%) respectively. There is a fair distribution of maternal health facilities across all the local government areas of the State. However, the 6 urban LGAs of Aba North, Aba South, Osisioma, Ugwunagbo, Umuahia North and Umuahia South had 31 of the Basic Essential Obstetric Care facilities and 61 of the Comprehensive Obstetric Care facilities while the 11 rural LGAs had only 11 Basic Essential Obstetric Care and 18 Comprehensive Essential Obstetric Care facilities (see Table 1).

Table 1. Classification of health facilities according to Essential Obstetric Care status in Local Government Areas in Abia State

\begin{tabular}{lllll}
\hline & \multicolumn{2}{l}{ Types of health facilities } & & \\
\cline { 2 - 4 } LGAs & $\begin{array}{l}\text { Non-Essential Obstetric } \\
\text { Care services }\end{array}$ & $\begin{array}{l}\text { Basic Essential Obstetric } \\
\text { Care services }\end{array}$ & $\begin{array}{l}\text { Comprehensive } \\
\text { Essential Obstetric Care } \\
\text { services }\end{array}$ & \\
\hline Aba North & 3 & 4 & 15 & 22 \\
Aba South & 30 & 16 & 22 & 68 \\
Arochukwu & 14 & 1 & 1 & 16 \\
Bende & 43 & 6 & 1 & 50 \\
Ikwuano & 15 & 0 & 0 & 15 \\
Isiala Ngwa North & 16 & 0 & 4 & 20 \\
Isiala Ngwa South & 10 & 0 & 2 & 12 \\
Isuikwuato & 29 & 0 & 2 & 31 \\
Ohafia & 15 & 0 & 2 & 17 \\
Obingwa & 7 & 1 & 2 & 10 \\
Osisioma & 9 & 6 & 9 & 24 \\
Ugwunagbo & 6 & 4 & 1 & 11 \\
Ukwa East & 5 & 1 & 2 & 8 \\
Ukwa West & 7 & 1 & 1 & 9 \\
Umuahia North & 9 & 0 & 11 & 20 \\
Umuahia South & 10 & 1 & 3 & 14 \\
Umunneochi & 21 & $\mathbf{4 2}$ & $\mathbf{3 9}$ & 23 \\
Total & $\mathbf{2 4 9}$ & & 2 & 2 \\
\hline
\end{tabular}

A total of 43 maternal deaths and 25,081 births were recorded during the study period giving a maternal mortality ratio of 171 per 100,000 live births. The 6 urban local government areas had a disproportionate share of the deliveries in the State as they accounted for 73.3\% (18391) of it. The urban LGAs recorded a total of 23 maternal deaths while the rural LGAs recorded 20 giving maternal mortality ratio of 125 per 100,000 for the urban LGAs and 299 per 100,000 for the rural LGAs. There is no statistical difference between the two values $\left(\chi^{2}=0.3307, \mathrm{~d} f=1, p>0.05\right)$ (see Table 2$)$. 
Table 2. Distribution of births and maternal deaths in Local Government Areas in Abia State

\begin{tabular}{lll}
\hline LGAs & Number of births & Number of maternal deaths \\
\hline Aba North & 2204 & 0 \\
Aba South & 10037 & 11 \\
Arochukwu & 449 & 1 \\
Bende & 947 & 0 \\
Ikwuano & 623 & 0 \\
Isiala Ngwa North & 213 & 4 \\
Isiala Ngwa South & 557 & 0 \\
Isuikwuato & 754 & 1 \\
Ohafia & 852 & 11 \\
Obingwa & 1085 & 2 \\
Osisioma & 1955 & 2 \\
Ugwunagbo & 460 & 0 \\
Ukwa East & 188 & 1 \\
Ukwa West & 276 & 0 \\
Umuahia North & 2980 & 10 \\
Umuahia South & 755 & 0 \\
Umunneochi & 746 & 0 \\
Total & $\mathbf{2 5 , 0 8 ~ 1}$ & $\mathbf{4 3}$ \\
\hline
\end{tabular}

Only one maternal death was recorded in all the primary care facilities in the State and that occurred in a Basic Essential Obstetric Care facility giving maternal mortality ratio of 13/100,000 for primary care facilities. So while the primary care facilities accounted for $30.5 \%$ of the births in the State, they represented only $2.3 \%$ of the maternal deaths.

Undue share of the maternal deaths were borne by the secondary public health care facilities. For while they represented only $6.5 \%$ (1634) of the births, they accounted for $32.6 \%$ of the recorded maternal deaths giving a maternal mortality ratio of 856.8 per 100,000 live births. The private secondary health care facilities catered for the majority of the deliveries in the State accounting for $63 \%(15,801)$ while an equivalent proportion of maternal deaths $(65 \%$; 28 deaths) were recorded by them during the same period giving MMR of 177/100,000 (see Table 3). The private Non-EOC facilities recorded 3,956 deliveries and 14 maternal deaths giving MMR of 354/100,000 while the private Comprehensive EOC recorded 11,135 deliveries and 14 maternal deaths giving MMR of 126/100,000. It is worthy of note to observe that in both the secondary public health facilities and in the secondary private health facilities that those health facilities that were Non Essential Obstetric Care fared poorly in their maternal mortality ratio. While the public Non-Essential Obstetric Care facilities recorded a maternal mortality ratio of 1070/100,000, the public Comprehensive Essential Obstetric Care facilities recorded a maternal mortality ratio of 829/100,000. However, there is no statistical difference between the two $\left(\chi^{2}\right.$ $=0.1104, \mathrm{~d} f=1, p>0.05)$. Similarly, while the private Non-Essential Obstetric Care facilities recorded a maternal mortality ratio of 354/100,000, the private Comprehensive Essential Obstetric Care facilities recorded a maternal mortality ratio of 126/100,000. The difference in the MMR between the private Non-Essential Obstetric Care facilities and the private Comprehensive Essential Obstetric Care facilities is statistically significant ( $2=8.1659, \mathrm{~d} f=1, p<0.05)$. 
Table 3. Distribution of births and maternal deaths according to types of health facilities

\begin{tabular}{|c|c|c|c|c|}
\hline Type of health facilitie & & Births & $\begin{array}{l}\text { Maternal } \\
\text { deaths }\end{array}$ & $\begin{array}{l}\text { Maternal mortality } \\
\text { Rate }\end{array}$ \\
\hline \multicolumn{5}{|l|}{ Primary care facilities } \\
\hline $\begin{array}{l}\text { Primary Health } \\
\text { Centers and Maternity }\end{array}$ & Non-Essential Obstetric Care facilities & 5,894 & 0 & 0 \\
\hline $\begin{array}{l}\text { Homes } \\
\text { (Both public and } \\
\text { private) }\end{array}$ & Basic Essential Obstetric Care facilities & $\begin{array}{l}1,752 \\
7646\end{array}$ & $\begin{array}{l}1 \\
1\end{array}$ & $\begin{array}{l}57.1 / 100,000 \\
\mathbf{1 3 . 1 / 1 0 0 , 0 0 0}\end{array}$ \\
\hline \multicolumn{5}{|c|}{ Secondary and tertiary care facilities } \\
\hline \multirow{3}{*}{ Public care facilities } & Non-Essential Obstetric Care facilities & 187 & 2 & $1069.5 / 100,000$ \\
\hline & $\begin{array}{l}\text { Comprehensive Essential Obstetric Care } \\
\text { facilities }\end{array}$ & 1,447 & 12 & $829.3 / 100,000$ \\
\hline & & 1634 & 14 & $856.8 / 100,000$ \\
\hline \multirow{4}{*}{ Private care facilities } & Non-Essential Obstetric Care facilities & 3956 & 14 & $353.9 / 100,000$ \\
\hline & Basic Essential Obstetric Care facilities & 710 & 0 & 0 \\
\hline & $\begin{array}{l}\text { Comprehensive Essential Obstetric Care } \\
\text { facilities }\end{array}$ & 11,135 & 14 & $125.7 / 100,000$ \\
\hline & & 15801 & 28 & $177.2 / 100,000$ \\
\hline \multicolumn{2}{|l|}{ Total } & 25,081 & 43 & 171.4/100,000 \\
\hline
\end{tabular}

\section{Discussion}

The large number of primary care facilities in the State involved in the delivery of maternal services is very encouraging. This may be a direct effect of the primary health care programme in the country, which has resulted in the establishment of several primary health care centres in LGAs of the State. The large presence of health facilities in the urban areas is responsible for the relatively large numbers of deliveries and maternal deaths recorded in them. Besides, the urban dwellers are expected to make better use of orthodox health facilities than their rural counterparts. Close to $70 \%$ of the maternal health facilities in the State are Non-Essential Obstetric Care and as such cannot cope with the major causes of maternal mortalities which are haemorrhage, prolonged obstructed labour, sepsis and pregnancy induced hypertension $^{[5,16,19-21]}$.

The preponderance of such weak health care facilities in the country might explain the high maternal mortality ratio of Nigeria.

The total number of maternal deaths of 43 recorded in the State with MMR of 171 per 100,000 for the study period is low. This may be as a result of poor documentation of records of maternal deaths by health facilities. Health facilities in the country exhibit laisser-faire attitude towards records of mortality neither are they compelled to notify appropriate authorities of the occurrence of deaths in their facilities nor are there provisions for investigation of the deaths. Similarly compliance to the issuance of death certificates to relations of the deceased before burial is not strictly observed. As a result, data on mortality is haphazardly maintained and their retrieval an uphill task. Instituting necessary regulations guiding the documentation, notification and reviewing of maternal deaths is necessary for proper implementation of maternal health programmes in the country ${ }^{[5]}$. Until we do this, we may never have reliable data on maternal deaths nor 
have yard sticks to monitor maternal health in the country and will be compelled to use process indicators to monitor the progress of maternal health programmes in the country as recommended by the World Health Organisation8.

The low MMR of 171/100,000 recorded in this study may not completely appear strange as a previous survey have found similarly low MMR for the country; The 1999 Nigeria Demographic and Health Survey obtained MMR of 289/100,000 for the nation which was however turned down on the grounds that the value does not tally with the other development indices of the country at that time9. So while exploring explanations for the low MMR in this study, it might be necessary to also consider that the proximate determinants for MMR for the state is good in comparison to what is obtainable in many other parts of the country; while the proportion for facility delivery is $74.4 \%$ and skilled assistance at birth is $87.1 \%$ in the State, the national average is $35 \%$ and $38.9 \%$ respectively ${ }^{[11]}$. Expectedly, the MMR for the State is bound to be relatively low.

Alternatively, the low maternal mortality ratio in the primary care facilities may be as a result of the fact that the services at the primary health centres/maternity homes are patronised more by mothers with low risk of obstetric complications or that when pregnant mothers are perceived to be at risk of major obstetric complications they are referred to higher levels of care. The other explanation may be poor documentation of maternal deaths at the primary care level.

A number of reasons may account for the high MMR obtained in public secondary health care facilities in the State. The public health facilities are more likely to comply with documentation of maternal mortality data since maintenance of health records is supposed to be part of their routine duties. Besides, they are more likely to have trained staff in their employ to carry out such responsibilities. In addition, the public health facilities are more likely to accept patients in bad state of health and are likely to receive large numbers of referrals for mothers with obstetric emergencies. Another reason could be the fact that many public referral centres are ill prepared to cope with obstetric emergencies as a national survey revealed that less than a third of the public sector referral health facilities in Nigeria met the standard for Comprehensive Essential Obstetric Care ${ }^{[22]}$. Besides, even in situations where public referral centres meet the EOC criteria for comprehensive EOC, many of them offer the services when it is too late to salvage the lives of mothers ${ }^{[23-25]}$.

Other studies in Nigeria have recorded high maternal mortalities in health facilities. Many of these studies have been in tertiary institutions. Harrison KA recorded 1050/100,000 deliveries in Zaria ${ }^{[26]}$, while 2,151/100,000, 2,397.3/100,000 and 739/100,000 were recorded in tertiary hospitals in Sokoto, Enugu and Jos respectively ${ }^{[27-29]}$. The MMR obtained from surveys of secondary health facilities in Anambra State and Ibadan were 497/100, 000 and 200/100, 000 respectively ${ }^{[30,31]}$. The tertiary facilities have higher prevalence of high risk pregnancies than the secondary and therefore record more fatalities ${ }^{[31]}$. Therefore, the MMR of 171/100,000 found in this study may be as a result of inclusion of both secondary and primary health facilities whose clientele have lower prevalence of high risk pregnancies.

The classification of health facilities on the Essential Obstetric Care status correlated well with their performance on MMR. Both public and private health facilities that did not meet the EOC criteria fared poorly in the handling of maternal health as the Non-EOC facilities recorded higher MMR than those facilities that were classified as Comprehensive EOC. The populace generally regard most general hospitals and private hospitals as referral centres for obstetric emergencies without knowledge of their EOC status. As a result, they make referrals to them without knowledge of their competence. It might be necessary to properly designate all health facilities offering maternal services in the country based on their EOC status and the populace properly informed so that decisions on referral of obstetric emergencies to facilities will be based on evidence of competence.

The low MMR recorded in the private Comprehensive EOC is very encouraging. It reveals their competence in handling obstetric emergencies. No wonder such facilities had good patronage and played significant role in child deliveries accounting close to $50 \%$ of all the births in the State. Another likely reason for the low MMR in private Comprehensive EOC is the fact that the facilities may not be forthcoming with data on maternal deaths as they may feel that providing information on maternal deaths may damage the reputation of their hospitals. In the absence of strong regulation on 
maintenance, reporting and investigation of maternal mortality, health facilities are likely to continue to be unserious in their handling of maternal data. Several studies in Nigeria have expressed concern over the documentation of maternal health records and have called for measures for systematic collection of data on maternal deaths ${ }^{[15,3032]}$.

Maintenance of data on maternal deaths is crucial to the implementation of maternal health programmes in the country. It is high time that necessary measures are put in place to effect proper handling of maternal records. This will provide the baseline data for planning, implementation, monitoring and evaluation of maternal health programmes in Nigeria.

\section{Acknowledgement}

We wish to express our thanks to UNFPA Abuja office for their support for the study and permission to use the findings for publication. We wish to also thank the Department of Community Development and Population Activities, Federal Ministry of Health, Abuja and Dr Fatusi O Adesegun the National Coordinator of the survey for their support.

\section{References}

[1] Kurjak A, Bekavac I. Perinatal problems in developing countries: lessons learned and future challenges. J-Perinat-Med. 2001; 29(3): 179-87. PMid:11447922 http://dx.doi.org/10.1515/JPM.2001.027

[2] Ghosh MK. Maternal mortality. A global Perspective. J Reprod Med. 2001; 46(5): 427-33. PMid:11396367

[3] Hill K, AbouZhar C, Wardlaw T. Estimates of maternal mortality for 1995. Bull World Health Organ. 2001; 79(3): 182-93. PMid:11285661

[4] Robinson JJ, Wharrad H. The relationship between attendance at birth and maternal mortality rates: an exploration of United Nations data sets including the ratios of physicians and nurses to population, GNP per capita and female literacy. J Adv Nurs. 2001; 34(4): 445-55. http://dx.doi.org/10.1046/j.1365-2648.2001.01773.x

[5] Bouvier-Colle MH, Ouedraogo C, Dumont A, Vangeenderhuysen C, Salanave B, Decam C. Maternal Mortality in West Africa. Rates, causes and substandard care from a prospective survey. Acta Obstet Gynecol Scand. 2001; 80(2): 113-9. PMid:11167204 http://dx.doi.org/10.1080/j.1600-0412.2001.080002113.x

[6] Smith JB, Fortney JA, Wong E, Amatya R, Coleman NA, de-Graft-Johnson J. Estimates of the maternal mortality ratio in two districts of the Brong-Ahafo Region, Ghana. Bull World Health Organ. 2001; 79(5): 400-8. PMid:11417035

[7] Olsen BE, Hinderaker SG, Bergsjo p, Lie RT, Olsen OH, Gasheka P, Kvale G. Causes and characteristics of maternal deaths in rural northern Tanzania. Acta Obstet Gynecol Scand. 2002; 81(12): 1101-9. PMid:12519105 http://dx.doi.org/10.1034/j.1600-0412.2002.811202.x

[8] Gottlieb P, Lindmark G. WHO indicators for evaluation of maternal health care services, applicability in least developed countries: a case study from Eritrea. Afr J Reprod Health. 2002; 6(2): 13-22. PMid:12476713 http://dx.doi.org/10.2307/3583126

[9] National Population Commission (Nigeria). 2000. Nigeria Demographic and Health Survey 1999. Calverton, Maryland: National Population Commission and ORC/Macro: 112-113.

[10] National Population Commission (NPC) [Nigeria] and ORC Macro.2004. Nigeria Demographic and Health Survey 2003. Calverton, Maryland: National Population Commission and ORC Macro.

[11] National Population Commission (NPC) [Nigeria] and ICF Macro.2009. Nigeria Demographic and Health Survey 2008. Abuja, Nigeria: National Population Commission and ICF Macro.

[12] Berg CJ, Chang J, Callaghan WM, Whitehead SJ. Pregnancy related mortality in the United States, 1991-1997. Obstet Gynecol 2003; 101(2): 289-96. http://dx.doi.org/10.1016/S0029-7844(02)02587-5

[13] Panchal S, Arria AM, Labhsetwar SA. Maternal mortality during hospital admission for delivery: a retrospective analysis using a state-maintained database. Anesth Analg. 2001; 93(1): 134-41. PMid:11429354 http://dx.doi.org/10.1097/00000539-200107000-00028

[14] Horon IL, Cheng D. Enhanced surveillance for pregnancy-associated mortality-Maryland, 1993-1998. JAMA. 2001; 285(11): 1455-9. PMid:11255421 http://dx.doi.org/10.1001/jama.285.11.1455

[15] Oladapo OT, Adetoro OO, Fakeye O, Ekele BA, Fawole AO, Abasiattai A, Kuti O, Tukur J, Ande AB, Dada OA. National data system on near miss and maternal death: shifting from maternal risk to public health impact in Nigeria. Reprod Health. 2009 ; 6: 8. PMid:19508717 http://dx.doi.org/10.1186/1742-4755-6-8

[16] Maine D, Akalin MZ, Ward VM, Kamara A. The design and evaluation of maternal mortality programs. Center for population and family health, School of Public Health, Columbia University, New York 1997. 
[17] UNICEF/WHO/UNFPA. Guidelines for monitoring the availability and use of obstetric services. New York, UNICEF, 1997.

[18] United Nations. The Millennium Declarations. Resolution A/RES/55/2. New York, 2000. WHO/UNFPA/UNICEF/World Bank. Reduction of maternal mortality: A joint statement by WHO/UNFPA/UNICEF/World Bank. Geneva, WHO, 1999.

[19] Olukoya A, Ogunyemi Ma, Akitoye C O et al. Upgrading obstetric care at a secondary referral hospital, Ogun state, Nigeria. Int J Gynecol Obstet. 1997; 59 (Suppl 12): S2225-S230. http://dx.doi.org/10.1016/S0020-7292(97)00149-5

[20] Orji E O, Ogunlola I O, Onwudiegwu U. Brought in maternal deaths in south west Nigeria. J Obstet Gynaecol. 2002; 22(4): 385-8. PMid:12521460 http://dx.doi.org/10.1080/01443610220141326

[21] Harrison KA. Maternal mortality in developing countries. Br J Obstet Gynaecol. 1989 Jan; 96(1): 1-3. PMid:2647128 http://dx.doi.org/10.1111/j.1471-0528.1989.tb01567.x

[22] Federal Ministry of Health, Abuja. National study on essential obstetric care facilities in Nigeria, 2003; 9-18.

[23] Orji E O, Fasubaa OB, Onwudiegwu U, Dare FO, Ogunniyi SO. Decision-intervention interval in ruptured uteri in Ile-Ife, Nigeria. East Afr Med J. 2002; 79(9): 496-8. PMid:12625692

[24] Okaro JM, Umezulike AC, Onah HE, Chukwuali LI, Ezugwu OF, Nweke PC. Maternal mortality at the University of Nigeria Teaching Hospital, Enugu, before and after Kenya. Afr J Reprod Health. 2001; 5(2): 90-7. PMid:12471917 http://dx.doi.org/10.2307/3583434

[25] Olsen BE, Hinderaker SG, Bergsjo P et al. Causes and characteristics of maternal deaths in rural northern Tanzania. Acta Obstet Gynecol Scand; 2002; 81(12): 1101-9. PMid:12519105 http://dx.doi.org/10.1034/j.1600-0412.2002.811202.x

[26] Harrison KA. Maternal mortality - a sharper focus on a major issue of our time. Trop J Obstet Gynaecol. 1988 ; 1 (1): 9-13. PMid:12179289

[27] Audu LR, Ekele BA. A ten year review of maternal mortality in Sokoto, northern Nigeria. West Afr J Med. 2002 Jan-Mar; 21(1): 74-6. PMid:12081352

[28] Ozumba BC, Nwogu-Ikojo EE. Avoidable maternal mortality in Enugu, Nigeria. Public Health. 2008 Apr; 122(4): 354-60. Epub 2007 Oct 23. PMid:17959207 http://dx.doi.org/10.1016/j.puhe.2007.04.018

[29] Ujah IA, Uguru VE, Aisien AO, Sagay AS, Otubu JA. How safe is motherhood in Nigeria? The trend of maternal mortality in a tertiary health institution. East Afr Med J. 1999 Aug; 76(8): 436-9. PMid:10520348

[30] Chukudebelu WO, Ozumba BC. Maternal mortality in Anambra State of Nigeria.Int J Gynaecol Obstet. 1998 Dec; 27 (3): $365-70$. http://dx.doi.org/10.1016/0020-7292(88)90114-2

[31] Otolorin EO, Marinho AO, Ojengbede O, Odukoya AO, Palmer CK. Maternity care monitoring: a contrast at two levels of health care delivery in Ibadan, Nigeria.

[32] Harrison KA.The struggle to reduce high maternal mortality in Nigeria. Afr J Reprod Health. 2009 Sep; 13(3): 9-20. PMid:20690258 